Article

\title{
Lean Tools, Knowledge Management, and Lean Sustainability: The Moderating Effects of Study Conventions
}

\author{
Bo Zhang ${ }^{1}$, Zhanwen Niu ${ }^{1}$ and Chaochao Liu ${ }^{2,3, *(1)}$ \\ 1 College of Management and Economics, Tianjin University, Tianjin 300072, China; \\ zzuzhangbo@163.com (B.Z.); zw.niu@163.com (Z.N.) \\ 2 School of Management, Tianjin University of Commerce, Tianjin 300134, China \\ 3 Research Center for Management Innovation and Evaluation, Tianjin University of Commerce, \\ Tianjin 300134, China \\ * Correspondence: liuchaotjcu@tjcu.edu.cn
}

Received: 6 January 2020; Accepted: 25 January 2020; Published: 28 January 2020

\begin{abstract}
It is essential for enterprises to develop lean sustainability. In this way, both the learning and understanding of the knowledge of lean tools becomes necessary. In fact, knowledge management plays a key role in the application of lean tools. In this paper, an in-depth exploration is carried out, investigating the mechanism of knowledge management which mediates between lean tools and the lean sustainability of enterprises, as well as the regulatory role of study conventions. Furthermore, a large sample from a questionnaire survey and a model based on structural equations is applied to test our theoretical hypothesis. It can be stated that lean tools display a positive effect on lean sustainability via the mediating role of knowledge management. Additionally, study conventions positively regulate the relationship among lean tools, knowledge management, and lean sustainability.
\end{abstract}

Keywords: lean sustainability; knowledge management; study conventions; structural equation model

\section{Introduction}

As an improvement tool of modern enterprise, the lean methodology brings advanced management ideas and business processes to companies [1]. The sustainable development of an enterprise is the sustainable development of lean implementation, but the lean implementation success rate in China is less than $30 \%$, and most implementations have been disposable. Therefore, elucidating how to improve the effect of lean implementation and improve the sustainability of lean implementation have become the areas of focus of various academic and business circles [2]. In the current knowledge economy, knowledge is not only the most important resource, but also an important source of power for ensuring a lean methodology. The improvement of production technology requires knowledge exploration, otherwise, it is difficult to meet the needs of modern enterprises [3].

In lean implementation, many lean tools are usually used to improve or solve problems in the process of management. The application of various tools is inseparable from the guidance of lean knowledge [4]. For example, visual management solves problems concerning being on-site and equipment, gradually developing standardized occupational habits and good professional qualifications. Pull planning realizes the self-management of each process [5]. Just-in-time products are made according to the time the products are needed, the quantity needed, and the specific products the customer needs. The implementation of these lean technologies and tools relies on the use of knowledge, whether it is explicit knowledge that has been encoded into a formal form of literature or work manual, or other tacit knowledge [6], such as individual behavior, experience, and expertise, 
which are all important factors for the use of lean tools [7]. The process of using lean tools is essentially a process of knowledge creation and flow. The use of knowledge management to conduct lean activities in production practice requires basic knowledge of lean methodology by the relevant personnel. At the same time, knowledge absorption, transformation, and storage can be completed in the course of practice [8]. The application of lean tools will also promote the transformation, activation, and use of knowledge to a certain extent.

Lean implementation is the elimination of waste through preventive measures so as to reduce environmental pollution while reducing costs. Lean product design automatically leads to greener products, and green product design ensures efficiency in the product development phase.

The purpose of lean is the application of a lean implementation system in the enterprise, which is a deep transformation of the enterprise system. This transformation is not to transform the existing system and process into a better one, but to build a cultural atmosphere for independent improvement within the enterprise. In other words, the enterprise needs to implant a gene that can continuously search for the best and form a dynamic mechanism. After the static mechanism is built, it can be run, while lean requires the establishment of the habit of optimization. It can be seen that lean emphasizes the cultivation of people's ability and habits, as well as the formation of corporate culture, which are the sustainability of lean.

Therefore, this paper defines lean sustainability from two aspects: from an environmental perspective, lean sustainability is the future development stage of lean implementation, in which enterprises pursue long-term environmental harmony and focus on the improvement of social value. Lean sustainability is to help enterprises change their operations to reduce waste, emissions and waste of resources. From the perspective of implementation, lean sustainability is defined as the establishment of the concept of long-term implementation of lean, the use of lean for in-depth transformation, continuous optimization, and the establishment of an independent implementation of lean cultural atmosphere within the enterprise.

The process of lean implementation is the management process of the transfer, sharing, integration, and transformation of lean knowledge in an enterprise. Knowledge management is an important area concerning the improvement of lean sustainability [9]. Recently, lean sustainability and knowledge management have gradually become common areas of concern for practitioners and academics. There have been many independent studies on the application of lean tools and knowledge management, both at home and abroad [10]. However, few scholars combine the application of lean tools with knowledge management to carry out sustainability analysis. Based on the process of lean implementation and its characteristics, this paper studies the role of knowledge management between lean tools and lean sustainability, establishing an internal relationship model between knowledge management, lean tools, and lean sustainability [11]. Additionally, the paper also studies the moderating effects of study conventions on the use of lean tools.

The article is structured as follows: a literature review is conducted in the next section. In the third section, on the basis of analyzing the theoretical background among lean tools, knowledge management, and lean sustainability, the hypothesis model of lean knowledge management ability is extracted. In the fourth section, the research methods are given. Then, the research result is verified by a case study. The conclusions and suggestions for future research are given in the final section.

\section{Related Work}

In order to grasp the current research status of knowledge management in lean implementation, this paper took lean as a keyword and used the Science Citation Index Expanded as a source of retrieval [12]. A total of 341 full-text academic articles were retrieved [13]. After excluding articles with short reviews, book reviews, and content discrepancies, 277 articles were finally obtained [14]. Between them, 65 were empirical articles. After a systematic reading of the articles mentioned, it was revealed that the principles and practices of lean production have been discussed by academics for decades. In fact, lean research began in the 1970s, but early researchers did not define lean in this 
instance. Sugimori published his first academic paper on the Toyota Production System (the prototype of lean production) in 1977 [15]. In 1988, Krafcik used "lean" to describe the manufacturing technology of Toyota for the first time [16]. In 1990, Womack et al. published "the machine that changed the world." In its discussion, the concept of lean production involves product development, procurement, the supply chain, production, and sales, among other things [17]. In 1996, Womack et al. proposed the concept of lean thinking, and raised the guiding principles of lean production to the corporate strategic level [18]. Since then, the growth of research on lean production has experienced a fast increase. In addition to manufacturing, other industrial sectors have applied lean thinking in order to transform their internal and external operations in order to gain competitive advantages [19]. From the perspective of research content, the previous studies on lean have been mainly divided into two directions, further explained below.

The first direction is traditional enterprise operation and production management, focusing on the value realization of lean production [20]. The second direction is to consider lean production as a paradigm for enterprise process optimization, in order to analyze the implementation of lean production in the given enterprise and to pay more attention to the internal organizational elements [21]. As one of the important factors affecting lean performance, the role of knowledge resources in the process of promoting lean production has gradually increased in interest [22]. Among the 65 empirical research studies of lean methodology, there were nine articles related to knowledge management. The content is shown in Table 1. 
Table 1. Empirical study of knowledge management in the application of lean tools.

\begin{tabular}{|c|c|c|c|c|}
\hline NO. & Time and Authors & Research Content & Sample & Research Methods \\
\hline 1 & $\begin{array}{l}2017 \\
\text { Amir Honarpour and Ahmad } \\
\text { Jusoh }\end{array}$ & $\begin{array}{l}\text { Propose a reciprocal causation between TQM and knowledge } \\
\text { management [23]. }\end{array}$ & & $\begin{array}{l}\text { Joint variance } \\
\text { analysis method }\end{array}$ \\
\hline 2 & $\begin{array}{l}2017 \\
\text { Yiwei Gong and Vincent } \\
\text { Blijleven }\end{array}$ & $\begin{array}{l}\text { The role of Lean principles in supporting knowledge management in } \\
\text { IT outsourcing relationships [24] }\end{array}$ & $\begin{array}{l}\text { Six semistructured interviews at } \\
\text { different organizational levels }\end{array}$ & Case study \\
\hline 3 & $\begin{array}{l}2017 \\
\text { M. FatihAcar, MerveTarim, } \\
\text { HalilZaim, SelimZaim and } \\
\quad \text { DursunDelen }\end{array}$ & $\begin{array}{c}\text { Find the level and direction of the relationship between ERP and } \\
\text { knowledge Management in the context of operational and financial } \\
\text { performance [25]. }\end{array}$ & $\begin{array}{l}\text { In total } 163 \text { responses are } \\
\text { collected from Turkish } \\
\text { manufacturing } \\
\text { companies }\end{array}$ & $\begin{array}{l}\text { Structural equation } \\
\text { modeling }\end{array}$ \\
\hline 4 & $\begin{array}{c}2017 \\
\text { MahaMohammed Yusr, } \\
\text { SanySanuriMohd Mokhtar, } \\
\text { Abdul Rahim Othman and } \\
\text { YatySulaiman }\end{array}$ & $\begin{array}{l}\text { Investigate the effect of applying total quality management (TQM) } \\
\text { on enhancing knowledge management processes. They also examine } \\
\text { the relationship between knowledge management and innovation } \\
\text { performance in the Malaysian manufacturing sector [26] }\end{array}$ & $\begin{array}{c}\text { In total } 800 \text { medium to large } \\
\text { manufacturing companies listed } \\
\text { in the Federation of Malaysian } \\
\text { Manufacturers }\end{array}$ & Partial least square \\
\hline 5 & $\begin{array}{l}2015 \\
\text { Satish Tyagi, XianmingCai, Kai } \\
\text { Yang and Terrence Chambers }\end{array}$ & $\begin{array}{c}\text { Establishes a framework to create knowledge in the product } \\
\text { development environment, and then systematically demonstrates } \\
\text { how these } 10 \text { lean tools and methods conceptually fit into and play a } \\
\text { significant role [27] }\end{array}$ & & SECI model \\
\hline 6 & $\begin{array}{l}2013 \\
\text { LudvigLindlof, Bjorn Soderberg } \\
\text { and MagnusPersson }\end{array}$ & $\begin{array}{l}\text { Establishes a link between the concept of lean product development } \\
\text { and the field of knowledge management [28]. }\end{array}$ & & SECI model \\
\hline 7 & $\begin{array}{l}2013 \\
\text { Shaofeng Liu, Mike Leat, } \\
\text { Jonathan Moizer, Phil Megicks } \\
\text { and DulekhaKasturiratne }\end{array}$ & $\begin{array}{l}\text { This paper proposes a decision-focused knowledge framework } \\
\text { including a multi-layer knowledge model, a knowledge matrix for } \\
\text { knowledge elicitation, and a decision tree for the design of the } \\
\text { knowledge base. A knowledge system for lean supply chain } \\
\text { management has been developed using artificial intelligence system } \\
\text { shells VisiRule and Flex [29]. }\end{array}$ & & $\begin{array}{c}\text { Multi-layer } \\
\text { knowledge model; }\end{array}$ \\
\hline 8 & $\begin{array}{c}2011 \\
\text { Bradley R.Staats, David James } \\
\text { Brunner, David M. Uptonc }\end{array}$ & $\begin{array}{l}\text { Document the influence of the lean initiative on internal processes } \\
\text { and examine how the techniques affect learning by improving both } \\
\text { problem identification and problem resolution [30]. }\end{array}$ & $\begin{array}{l}\text { An Indian software } \\
\text { services firm }\end{array}$ & Case study \\
\hline 9 & $\begin{array}{l}2010 \\
\text { GopeshAnand, Peter T. Ward } \\
\text { and Mohan V. Tatikonda }\end{array}$ & $\begin{array}{c}\text { This research develops a conceptual model for predicting the success } \\
\text { of process improvement projects as a result of knowledge-creation } \\
\text { practices employed in the projects [31]. }\end{array}$ & & $\begin{array}{l}\text { Hierarchical } \\
\text { regression }\end{array}$ \\
\hline
\end{tabular}


Lean implementation is an important means of production. Its role in knowledge management is self-evident [32]. However, in the actual lean practice process, relevant management personnel have obvious deficiencies in mastering lean knowledge [33]. Wandahl conducted a literature review and case study of lean implementation and found that $80 \%$ of people involved in lean-related work did not have lean knowledge and only $6 \%$ of staff knew and determined that they were using lean tools or lean production technology [34]. Brianna studied the common misconceptions in lean concepts, which were largely responsible for poor lean methodology implementations [35]. Therefore, strengthening the research and attention of knowledge here will lead to the successful implementation of lean sustainability. This means that knowledge is a crucial factor in the process of lean sustainability.

On the basis of the previous research, the knowledge management process was divided into three basic processes, namely, knowledge acquisition, knowledge integration, and knowledge application. This paper studies the impact of these three basic processes on lean performance. At the same time, it studies the effect of the adjustment of study routines on knowledge management. Specifically, the main research questions in this paper are as follows: How does the application of lean tools influence lean sustainability through the role of knowledge management? How does the application of lean tools affect knowledge management and lean sustainability in terms of study routine change?

\section{Theoretical Background and Research Hypothesis}

\subsection{Lean Tools and Knowledge Management}

The application of lean tools depends on the guidance of lean knowledge, while lean implementation will produce a lot of data, such as tables, graphics, Kanban charts, value flow charts, cost estimation tables, and so on [36]. The use of lean tools is actually a process of knowledge creation, transformation, storage, and application. Therefore, it is incomplete to treat the application process of lean tools simply as a practical method to eliminate waste and increase efficiency [37]. Many scholars are actively studying the effect of various improvements and management level improvements on knowledge management in the process of lean implementation [38]. Frank established the basic element framework of a complex quality management project against the background of six sigma and examined the role of these elements in promoting organizational learning and knowledge creation [39]. Tyagi, who took a comprehensive dynamic knowledge creation model (the SECI model), explored how lean tools promoted and improved the efficiency of the process of knowledge creation in new product development projects through a deductive approach [40]. Zwain believed that modern quality management research has focused on quality management strategies [24] and rarely considered the impact of quality management practices on the knowledge creation process. Therefore, a model of the relationship between quality management practice and the knowledge creation process was constructed [41]. After data inspection, it was found that five quality management measures, such as employee training, employee participation, product design, benchmark design, and vision statement, had a significant impact on the knowledge creation process. The first set of hypotheses of the present work are presented below:

- Hypothesis 1a: The application of lean tools has a positive effect on knowledge acquisition

- Hypothesis 1b: The application of lean tools has a positive effect on knowledge integration

- Hypothesis 1c: The application of lean tools has a positive effect on knowledge application

\subsection{The Basic Process and Interaction of Knowledge Management}

Knowledge is a key resource for a company, used in order to maintain a sustainable competitive advantage. There is no strict sequence among knowledge acquisition, knowledge integration, and knowledge application. Knowledge acquisition is a process of searching and evaluating all kinds of knowledge that are related to production technology and the acquirement of new knowledge [42]. New knowledge generated by knowledge acquisition becomes the raw material of knowledge integration [43]. The quality of acquired knowledge affects the efficiency of knowledge integration. Therefore, knowledge 
acquisition has a positive impact on knowledge integration. The integration of knowledge is a process of knowledge storage and transformation [44]. After systems, knowledge integration can be better applied to guide a company's production practice process. Therefore, knowledge integration has a positive impact on the application of knowledge [45]. In the process of using knowledge to guide enterprises in their production practices, relevant personnel will evaluate existing knowledge and improve some of the current production processes. In the process of continuous learning and improvement in an application, enterprises increase their knowledge stock and knowledge acquisition have a positive impact on knowledge applications. In the study of evaluating enterprise knowledge management practices, Gold et al. [2] divided the knowledge management process into four subprocesses, based on the "knowledge substantiation" hypothesis, which were acquisition, transformation, application, and protection, and these were quantified separately. Maryam and Dorothy [46] pointed out that knowledge management included knowledge storage/activation, knowledge transfer, and knowledge application. Garud and Nayyar believed that the technological learning process involved three stages, namely, knowledge selection, knowledge storage, and knowledge activation and integration. Carlile and Rebentisch pointed out that a knowledge transfer cycle includes knowledge storage, knowledge activation, and knowledge transfer [47]. The second set of hypotheses of the present work are presented below:

- Hypothesis 2a: knowledge acquisition has a positive impact on knowledge integration

- Hypothesis 2b: knowledge integration has a positive impact on knowledge application

- Hypothesis 2c: knowledge acquisition has a positive impact on knowledge application

\subsection{Knowledge Management and Lean Sustainability}

Due to increasingly fierce global competition, enterprises are paying more and more attention to the real benefits brought about by knowledge [48]. Knowledge has become an important factor in the difference between enterprises and competitors and has become an effective way for enterprises to organize properly. From the aspects of technology and society, Arumugan et al. studied the impact of organizational resources and team psychological security on organizational learning behavior, knowledge creation, and the success of Six Sigma process improvement projects in Six Sigma environments. The results show that psychological security affects the performance of the project through knowledge [49]. Anand established a conceptual model to explore the relationship between the knowledge creation practice and the success of the process improvement project [50]. In the considered Six Sigma black belt project, the model was empirically studied. The results affirmed the knowledge creation practice put forward by Reich, verifying the intermediate adjustment of knowledge management through knowledge consistency. The use of the project had an impact on the performance of the project [51]. Zheng investigated the effect of organizational culture, organizational structure, and organizational strategy on organizational effectiveness through the intermediate regulation of knowledge management [52]. The theoretical and empirical results supported this hypothesis. Many studies consider that the continuous access to knowledge of enterprises is the foundation of competitive advantages, and knowledge acquisition can promote lean sustainability [53]. Effective knowledge management promotes constant transfer and improves the availability of knowledge. Knowledge management also increases the base knowledge of the whole team, such that the effectiveness to accomplish tasks is increased quickly, not only in quality but also in quantity, achieving good performance goals. The third set of hypotheses of the present work are presented below:

- Hypothesis 3a: Knowledge acquisition has a positive effect on lean sustainability

- Hypothesis 3b: Knowledge integration has a positive impact on lean sustainability

- Hypothesis 3c: Knowledge applications have a positive impact on lean sustainability 


\subsection{Lean Tools and Lean Sustainability}

In the face of fierce market competition, the introduction of lean tools has become the best choice for many industries and companies [54]. The relationship between the adoption of lean tools and corporate sustainability performance has been valued by both the theoretical and business communities. Nair conducted empirical research on quality management practices and applied meta-analysis to analyze the significance of the relationship between lean implementation and operational sustainability [55]. Ataseven and Nair applied meta-analysis to explore the relationship between supply chain integration and operational sustainability [56]. Most of the studies in this area are case studies, relying on corporate engineering practices and using qualitative methods to analyze the role of lean implementation (e.g., in business operations, efficiency, cost, inventory, and so on [57]). Since then, the focus of lean production on application research has shifted to the empirical research of lean implementation activities and business performance, exploring the relationship between lean practice activities and corporate performance [58]. The view that the use of lean tools can improve operational sustainability is continuously empirically supported. For example, Belekukias selected five classic lean practice activities as research objectives and explored the relationship between these practical activities and operational sustainability. The study found that JIT and self-destruction have a significant positive impact on operational sustainability [59]. The fourth hypothesis of the present work is presented below:

- Hypothesis 4a: The use of lean tools has a positive effect on lean sustainability

\subsection{The Moderating Effect of Study Convention}

Convention is a key word in the field of organizational theory. H.R. and T.D.D. pointed out that the formal sustainability of conventions includes engineering drawings, financial audits, digital data, text descriptions, and so on [60]. Here, the informal presentation includes the daily speech, posture, description of the event, etc. This paper defines the frequent and interactive behaviors in the use of lean tools around different stages of knowledge acquisition, knowledge integration, and knowledge applications as study conventions [61]. Previous studies have pointed out that learning processes around knowledge acquisition, integration, and application have been influenced by study conventions at different stages of learning [62]. This concept mainly deals with three types of activities. One is to add new knowledge to the existing knowledge for regular use in the future, the second is to integrate the stored knowledge when the company discovers opportunities or problems, and the third is the application of the integrated knowledge in the actual production process. Cohen and Levinthal believed that [63] organizing the establishment of study conventions could promote knowledge management and help when attempting to learn and absorb new knowledge and enhance competitive advantages. Zahra and George pointed out that there are study conventions in the process of acquiring, absorbing, transforming, and utilizing knowledge [64]. Galinic and Rodan [65] believed that study conventions could help to promote knowledge integration and promote the identification and absorption of complex knowledge. This paper believes that the use of lean tools, through the adjustment of study conventions, can result in better acquiring, integrating, and applying knowledge. The fifth set of hypotheses of the present work are presented below:

- Hypothesis 5a: Study conventions positively modulate the relationship between lean tools and knowledge acquisition

- Hypothesis 5b: Study conventions positively modulate the relationship between lean tools and knowledge integration.

- Hypothesis 5c: Study conventions positively modulate the relationship between lean tools and knowledge application.

- Hypothesis 5d: Study conventions positively modulate the relationship between lean tools and lean sustainability.

The diagram of this paper is shown in Figure 1. 


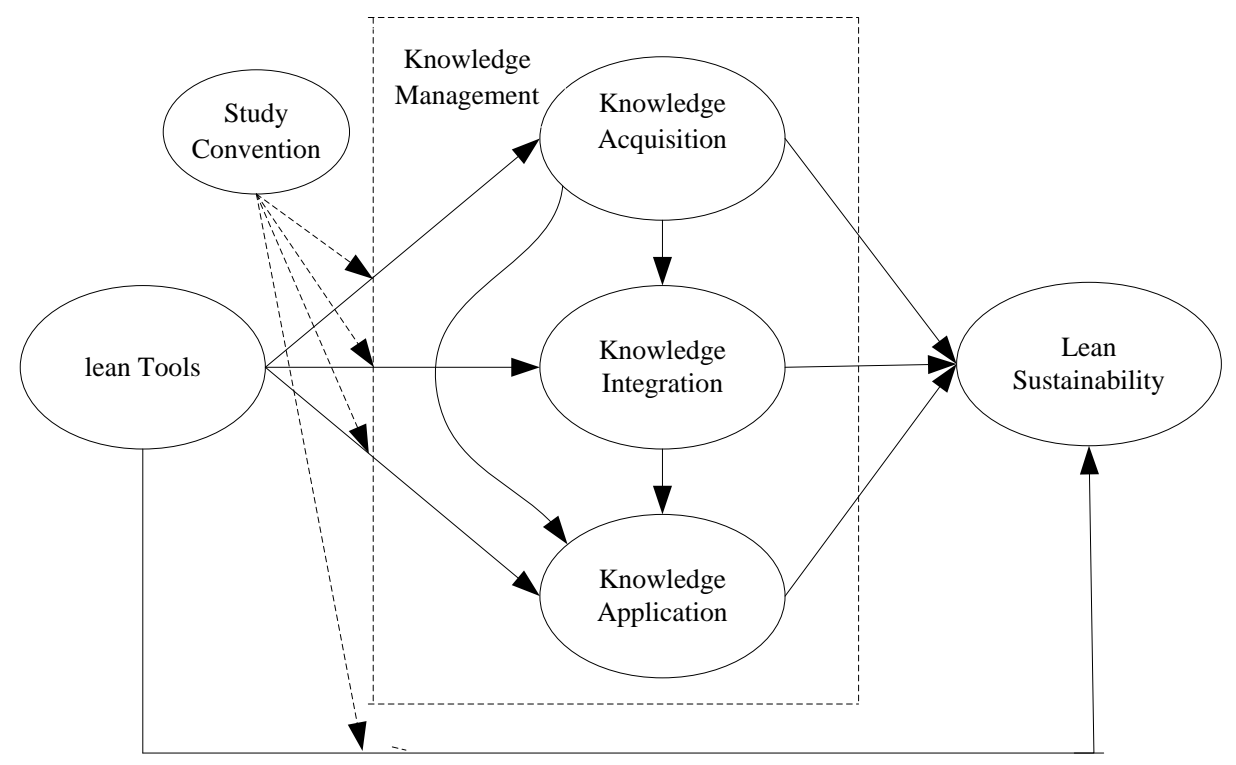

Figure 1. Proposed model.

\section{Research Methods}

\subsection{Samples Election and Data Collection}

This paper adopted a questionnaire survey method to collect data and support the hypotheses. The survey samples were mainly collected from companies implementing lean projects in Beijing, Tianjin, and Weifang, and the respondents were all staff specialized in lean implementation and management. Respondents filled out questionnaires depending on the lean construction project they were participating in. We distributed 500 questionnaires and recovered 463. We eliminated questionnaires with incomplete or distorted information and finally obtained 394 valid questionnaires [66].

\subsection{Variable Measurement}

The main variables measured in this paper are as follows: The questionnaire was designed to use a seven-point Likert representation. Here, 1 indicates very inconsistent and 7 indicates full compliance.

\subsubsection{Lean Tools}

In this paper, nine lean tools were selected through the literature review and quantified by using the actual frequency in the given enterprise. The measurement indicators were visual management (LT1), JIT (LT2), Kanban management (LT3), zero inventory management (LT4), total production maintenance (TPM, LT5), value stream mapping (LT6), production line balance design (LT7), pulling production (LT8), and continuous improvement (LT9).

\subsubsection{Knowledge Management}

The measurement of knowledge management refers to the knowledge management process measurement scale of GOLD, which divides the knowledge management process into three dimensions, namely, knowledge acquisition (KA), knowledge integration (KI), and knowledge application (KU).

For the measurement of knowledge acquisition, this paper draws on the knowledge acquisition scale of Islam and has designed four items to measure knowledge acquisition, namely, encouraging professional lean staff to perform rotations (KA1), the use of important lean tools (KA2), ensuring that there is enough attraction to keep key employees in the enterprise (KA3), and supporting the sharing of lean knowledge (KA4). 
The measurement of knowledge integration was based on the knowledge integration scale of Jansen and uses five indicators to measure knowledge integration, namely, building a corporate lean knowledge base, managing all kinds of lean tools and lean technologies (KI1), improving the archiving and preservation of lean tool promotion-related materials (KI2), identifying various lean tools and their use quickly (KI3), paying attention to the original lean knowledge data of the company, carrying out bulk importation, and incorporating it into the management scope (KI4), and finally, integrating mature lean tools and making improvements (KI5).

For the measurement of knowledge applications, this article mainly refers to the scale of Shenkar (Shenkar O., Li J., 1999), and uses four scales to measure knowledge applications, namely, the building of a lean knowledge map and understanding the distribution of various lean tools and lean technologies clearly, in order to provide a basis for management decisions (KU1); building a lean authority system, with different levels of open knowledge for employees of different roles and ensuring corporate knowledge security (KU2); setting up lean expert groups specifically and guiding lean production (KU3); and finally, being good at using lean production tools to solve new problems (KU4).

\subsubsection{Lean Sustainability}

An evaluation of lean sustainability, as implemented in the business management of the given company, involving machinery, the environment, and management, was carried out. This article reflects the lean sustainability of enterprises from all aspects of personnel, machinery, the environment, and management, from the perspective of system integration. The lean sustainability measures used to evaluate the results can be divided into four groups: (1) Personnel, specifically, employee involvement levels (LP1) and customer satisfaction (LP2); (2) Machine, specifically, startup time (LP3), on-time delivery (LP4), and product quality (LP5); (3) Environment, specifically, plant environmental improvement (LP6), waste disposal (LP7), and resource utilization efficiency (LP8); (4) Management, specifically, communication (LP9), market share, and training management level (LP10).

\subsubsection{Study Convention}

This article mainly refers to Breschi's research, using four scales to measure learning practices (Breschi, S., Lissoni, F. 2001), namely, employee execution level (SR1), shared language (SR2), internal learning mechanisms (SR3), and willingness to receive new methods (SR4).

\section{Research Results}

\subsection{Descriptive Statistics}

In mathematical statistics, skewness and kurtosis are often used to judge whether the data obey a normal distribution. When skewness and kurtosis are less than 3, the data satisfy the requirements for a normal distribution. This paper makes descriptive statistical comments on the LT, SR, KA, KI, KU, and LP scales, including the information concerning the means, deviations, skewness, kurtosis, and so on, in order to determine the basic level of the title and the distribution of the data in the scale. As shown in Table 1, the skewness of each topic is between -1.027 and 0.610 , and the kurtosis is between -1.225 and 0.397 . The absolute value of the skewness and kurtosis is less than 3 , indicating that each topic obeys a normal distribution.

\subsection{Reliability Analysis}

In order to ensure the reliability and stability of the questionnaire, this paper uses an $\alpha$ coefficient (i.e., Cronbach's $\alpha$ coefficient) to test the reliability. The larger the $\alpha$ coefficient, the higher the questionnaires reliability, that is, the credibility and stability of the questionnaire is higher. Table 2 shows that the $\alpha$ coefficients of LT, SR, KA, KI, KU, and LP are $0.916,0.863,0.832,0.873,0.870$, and 0.918 , respectively, all of which are greater than 0.8 , indicating that the variables have excellent reliability. In addition, the overall Cronbach $\alpha$ coefficient of the questionnaire is 0.946 , which is more than 0.9 , 
indicating that the whole questionnaire has excellent reliability. Reliability statistics are shown in Table 3 .

Table 2. Descriptive statistics of scale.

\begin{tabular}{|c|c|c|c|c|c|c|c|}
\hline & Capacity & Minimum & Maximum & Mean & Deviation & Skewness & Kurtosis \\
\hline WeL.T1 & 394 & 1.00 & 7.00 & 4.241 & 1.898 & -0.300 & -0.761 \\
\hline LT2 & 394 & 1.00 & 7.00 & 4.447 & 1.829 & -0.342 & -0.755 \\
\hline LT3 & 394 & 1.00 & 7.00 & 4.338 & 1.827 & -0.259 & -0.886 \\
\hline LT4 & 394 & 1.00 & 7.00 & 4.365 & 1.923 & -0.213 & -1.019 \\
\hline LT5 & 394 & 1.00 & 7.00 & 4.429 & 1.829 & -0.291 & -0.873 \\
\hline LT6 & 394 & 1.00 & 7.00 & 4.459 & 1.849 & -0.315 & -0.891 \\
\hline LT7 & 394 & 1.00 & 7.00 & 4.272 & 1.831 & -0.124 & -0.886 \\
\hline LT8 & 394 & 1.00 & 7.00 & 4.124 & 1.735 & -0.084 & -0.703 \\
\hline LT9 & 394 & 1.00 & 7.00 & 5.051 & 1.928 & -0.755 & -0.500 \\
\hline SC1 & 394 & 1.00 & 7.00 & 4.091 & 2.013 & 0.081 & -1.101 \\
\hline SC2 & 394 & 1.00 & 7.00 & 4.023 & 1.821 & 0.009 & -0.927 \\
\hline SC3 & 394 & 1.00 & 7.00 & 4.010 & 1.687 & -0.163 & -0.770 \\
\hline SC4 & 394 & 1.00 & 7.00 & 3.987 & 1.755 & 0.005 & -0.600 \\
\hline KA1 & 394 & 1.00 & 7.00 & 4.728 & 1.817 & -0.394 & -0.809 \\
\hline KA2 & 394 & 1.00 & 7.00 & 4.645 & 1.866 & -0.381 & -0.852 \\
\hline KA3 & 394 & 1.00 & 7.00 & 3.066 & 1.755 & 0.509 & -0.631 \\
\hline KA4 & 394 & 1.00 & 7.00 & 3.368 & 1.894 & 0.340 & -0.946 \\
\hline KI1 & 394 & 1.00 & 7.00 & 3.332 & 1.831 & 0.234 & -0.907 \\
\hline $\mathrm{KI} 2$ & 394 & 1.00 & 7.00 & 4.652 & 1.961 & -0.389 & -0.912 \\
\hline KI3 & 394 & 1.00 & 7.00 & 4.485 & 2.083 & -0.348 & -1.104 \\
\hline KI4 & 394 & 1.00 & 7.00 & 4.759 & 1.955 & -0.503 & -0.798 \\
\hline KI5 & 394 & 1.00 & 7.00 & 4.858 & 1.886 & -0.546 & -0.695 \\
\hline KU1 & 394 & 1.00 & 7.00 & 4.340 & 1.991 & -0.214 & -1.002 \\
\hline KU2 & 394 & 1.00 & 7.00 & 4.914 & 1.713 & -0.348 & -0.709 \\
\hline KU3 & 394 & 1.00 & 7.00 & 4.827 & 1.795 & -0.381 & -0.831 \\
\hline KU4 & 394 & 1.00 & 7.00 & 4.685 & 1.944 & -0.355 & -0.992 \\
\hline LP1 & 394 & 1.00 & 7.00 & 3.112 & 2.028 & 0.610 & -0.837 \\
\hline LP2 & 394 & 1.00 & 7.00 & 4.909 & 2.113 & -0.655 & -0.888 \\
\hline LP3 & 394 & 1.00 & 7.00 & 5.264 & 2.201 & -0.986 & -0.514 \\
\hline LP4 & 394 & 1.00 & 7.00 & 5.058 & 2.196 & -0.773 & -0.831 \\
\hline LP5 & 394 & 1.00 & 7.00 & 4.964 & 2.055 & -0.712 & -0.751 \\
\hline LP6 & 394 & 1.00 & 7.00 & 4.756 & 1.959 & -0.535 & -0.827 \\
\hline LP7 & 394 & 1.00 & 7.00 & 5.272 & 2.181 & -1.027 & -0.397 \\
\hline LP8 & 394 & 1.00 & 7.00 & 3.480 & 1.947 & 0.311 & -0.924 \\
\hline LP9 & 394 & 1.00 & 7.00 & 3.513 & 2.033 & 0.247 & -1.113 \\
\hline LP10 & 394 & 1.00 & 7.00 & 3.924 & 2.105 & 0.029 & -1.225 \\
\hline
\end{tabular}

Table 3. Reliability statistics.

\begin{tabular}{cccccccc}
\hline Variables & LT & SC & KA & KI & KU & LP & ALL \\
\hline Cronbach $\alpha$ & 0.916 & 0.863 & 0.832 & 0.873 & 0.870 & 0.918 & 0.943 \\
\hline
\end{tabular}

\subsection{Validity Analysis}

This paper uses factor analysis to test the validity of the questionnaire. Before doing a factor analysis, we must determine whether the questionnaire is suitable for factor analysis, which requires the use of SPSS to find the KMO value and Bartlett's sphere test. If the KMO value is larger than 0.7 and $P$ is less than 0.05 , the questionnaire is suitable for factor analysis.

Firstly, exploratory factor analysis was performed using the principal component method. The common factor extracted was rotated by the maximum variance method, then the obtained factor matrix was selected, only keeping factors whose loading was greater than 0.5. We used Amos version 23.0 as the tool for confirmatory factor analysis. 


\subsubsection{Exploratory Factor Analysis}

It can be seen from Table 4 that the KMO test value of the survey data is 0.948 , which is greater than 0.70 , indicating that the questionnaire is suitable for factor analysis. The results from Bartlett's sphericity test show that the approximate chi-squared value is 7965.502 and the value of statistical significance is $<0.001$. Therefore, the null hypothesis of Bartlett is rejected and the validity of the scale is considered well-structured and suitable for factor analysis.

Table 4. KMO and Bartlett sphere test.

\begin{tabular}{cccc}
\hline KMO & \multicolumn{3}{c}{ Bartlett Sphere Test } \\
\hline \multirow{2}{*}{0.948} & Approximate chi-square, & degrees of freedom, & significance \\
& 8098.095 & 630 & 0.000 \\
\hline
\end{tabular}

In this study, principal component analysis was adopted and factor rotation was performed by using the maximum orthogonal rotation of variance. Factors with an eigenvalue larger than 1 were extracted. There were six common factors with a characteristic value greater than 1 , and the cumulative variance contribution rate of the six principal components was $64.441 \%$, which is larger than $60 \%$. It is stated that the six common factors proposed in this study can effectively explain 36 topics of the scale and achieve the purpose of factor reduction. This is shown in Table 5.

Table 5. Interpretation of total variance.

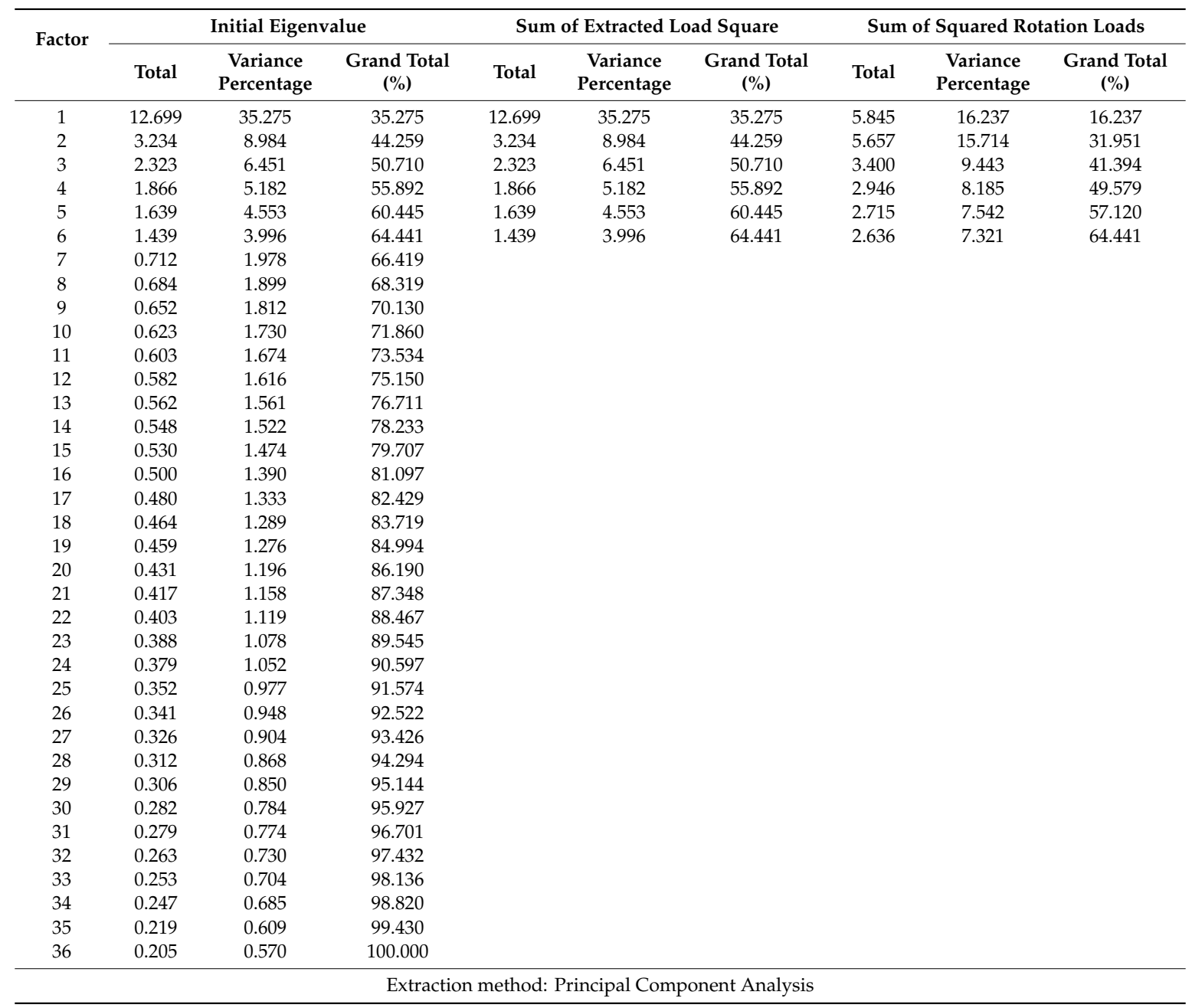


As can be seen from Table 6, the factor loading of each principal component after rotation is more than 0.5 , indicating that these topics can fit well into the corresponding latitudes. The framework validity of this study is very good.

Table 6. Rotated component matrix.

\begin{tabular}{|c|c|c|c|c|c|c|c|}
\hline \multirow{2}{*}{ Dimensions } & \multirow{2}{*}{ Topic } & \multicolumn{6}{|c|}{ Component } \\
\hline & & 1 & 2 & 3 & 4 & 5 & 6 \\
\hline \multirow{10}{*}{$\mathrm{LT}$} & LT1 & 0.074 & 0.706 & 0.121 & 0.037 & 0.173 & 0.063 \\
\hline & LT2 & 0.185 & 0.769 & 0.046 & 0.042 & 0.095 & 0.179 \\
\hline & LT3 & 0.186 & 0.786 & 0.135 & 0.018 & 0.125 & 0.080 \\
\hline & LT4 & 0.183 & 0.767 & 0.140 & 0.058 & 0.082 & 0.033 \\
\hline & LT5 & 0.147 & 0.666 & 0.156 & 0.047 & 0.099 & 0.110 \\
\hline & LT6 & 0.180 & 0.734 & 0.085 & -0.033 & 0.078 & 0.172 \\
\hline & LT7 & 0.175 & 0.767 & 0.049 & 0.051 & 0.114 & 0.123 \\
\hline & LT8 & 0.079 & 0.694 & 0.125 & 0.118 & 0.070 & 0.062 \\
\hline & LT9 & 0.251 & 0.698 & 0.145 & 0.014 & 0.026 & 0.200 \\
\hline & SC1 & 0.157 & 0.038 & 0.169 & 0.781 & 0.127 & 0.063 \\
\hline \multirow{3}{*}{ SC } & SC2 & 0.099 & 0.025 & 0.126 & 0.858 & 0.085 & 0.104 \\
\hline & SC3 & 0.082 & 0.138 & 0.097 & 0.818 & 0.049 & 0.096 \\
\hline & SC4 & 0.189 & 0.015 & 0.104 & 0.790 & 0.080 & 0.070 \\
\hline \multirow{4}{*}{ KA } & KA1 & 0.219 & 0.131 & 0.105 & 0.095 & 0.783 & 0.101 \\
\hline & KA2 & 0.178 & 0.187 & 0.177 & 0.075 & 0.748 & 0.141 \\
\hline & KA3 & 0.226 & 0.144 & 0.091 & 0.065 & 0.687 & 0.161 \\
\hline & KA4 & 0.254 & 0.188 & 0.058 & 0.141 & 0.749 & 0.078 \\
\hline \multirow{5}{*}{ KI } & KI1 & 0.265 & 0.235 & 0.767 & 0.107 & 0.144 & 0.153 \\
\hline & $\mathrm{KI} 2$ & 0.181 & 0.191 & 0.766 & 0.168 & 0.090 & 0.121 \\
\hline & KI3 & 0.183 & 0.138 & 0.680 & 0.140 & 0.108 & 0.148 \\
\hline & KI4 & 0.224 & 0.219 & 0.742 & 0.119 & 0.126 & 0.100 \\
\hline & KI5 & 0.231 & 0.074 & 0.737 & 0.079 & 0.030 & 0.098 \\
\hline \multirow{4}{*}{ KU } & KU1 & 0.233 & 0.196 & 0.187 & 0.095 & 0.166 & 0.764 \\
\hline & KU2 & 0.306 & 0.242 & 0.122 & 0.112 & 0.065 & 0.734 \\
\hline & KU3 & 0.259 & 0.249 & 0.190 & 0.099 & 0.218 & 0.625 \\
\hline & KU4 & 0.243 & 0.236 & 0.187 & 0.153 & 0.167 & 0.780 \\
\hline \multirow{10}{*}{ LP } & LP1 & 0.691 & 0.195 & 0.281 & 0.029 & 0.165 & 0.109 \\
\hline & LP2 & 0.746 & 0.169 & 0.080 & 0.019 & 0.009 & 0.216 \\
\hline & LP3 & 0.664 & 0.179 & 0.150 & 0.041 & 0.120 & 0.138 \\
\hline & LP4 & 0.665 & 0.190 & 0.055 & 0.146 & 0.166 & 0.070 \\
\hline & LP5 & 0.714 & 0.174 & 0.170 & 0.103 & 0.112 & 0.126 \\
\hline & LP6 & 0.773 & 0.109 & 0.130 & 0.138 & 0.140 & 0.151 \\
\hline & LP7 & 0.687 & 0.085 & 0.150 & 0.080 & 0.141 & 0.046 \\
\hline & LP8 & 0.592 & 0.173 & 0.232 & 0.114 & 0.218 & 0.138 \\
\hline & LP9 & 0.686 & 0.165 & 0.108 & 0.168 & 0.191 & 0.155 \\
\hline & LP10 & 0.692 & 0.267 & 0.243 & 0.082 & 0.117 & 0.181 \\
\hline
\end{tabular}

\subsubsection{Confirmatory Factor Analysis}

As shown in Table 7, the p-value of the model does not reach the ideal value, but the p-value is easily affected by the sample size. Therefore, this dissatisfaction cannot directly reject the model. In this case, we need to look at another fitting indicator. We can see that other indicators' GFI NFIs are all close to 0.9 . The rest of them all reach the ideal value. In general, the model can be verified by confirmatory factor analysis. 
Table 7. Confirmatory factor analysis fitting index.

\begin{tabular}{ccccc}
\hline Indicator & Statistic Value & Critical Value & Result & Model Fitting Judgment \\
\hline & $\chi^{2}$ & & 2015.493 & \\
Absolute fitting & df & & 1737 & \\
index & P & $\geq 0.05$ & 0.000 & NO \\
& SRMR & $\leq 0.05$ & 0.036 & YES \\
& RMSEA & $\leq 0.08$ & 0.014 & YES \\
& GFI & $\geq 0.90$ & 0.880 & Close to 0.9 \\
\hline & NFI & $\geq 0.90$ & 0.875 & Close to 0.9 \\
Value-added fitting & IFI & $\geq 0.90$ & 0.981 & YES \\
index & TLI & $\geq 0.90$ & 0.979 & YES \\
& CFI & $\geq 0.90$ & 0.981 & YES \\
\hline & PGFI & $\geq 0.50$ & 0.765 & YES \\
Simple fitting index & PNFI & $\geq 0.50$ & 0.805 & YES \\
& PCFI & $\geq 0.50$ & 0.901 & YES \\
& CN & $\geq 200$ & 717 & YES \\
& $\chi^{2} / \mathrm{df}$ & $\leq 2.00$ & 1.160 & YES \\
\hline
\end{tabular}

Table 8 is the result of verification factor analysis for LT, SC, KA, KI, KU, and LP. It can be seen that the CR of the whole scale and each variable is larger than 0.7, the AVE is larger than 0.5, and the standardized load coefficient of each item in its corresponding latent variable is larger than 0.6. These normalized estimates all satisfy the condition of $p<0.001$ and have strong significance. This shows that the six scales of this study have great combination reliability and convergent validity.

Table 8. Confirmatory factor analysis results.

\begin{tabular}{|c|c|c|c|c|c|c|c|c|c|}
\hline & & & Estimate & S.E. & C.R. & $\mathbf{P}$ & Standardized Estimate & CR & AVE \\
\hline LT1 & $<-$ & $\mathrm{LT}$ & 1.000 & & & & 0.686 & \multirow{9}{*}{0.917} & \multirow{9}{*}{0.551} \\
\hline LT2 & $<-$ & $\mathrm{LT}$ & 1.110 & 0.078 & 14.310 & $* * *$ & 0.790 & & \\
\hline LT3 & $<-$ & $\mathrm{LT}$ & 1.141 & 0.077 & 14.743 & $* * *$ & 0.813 & & \\
\hline LT4 & $<-$ & $\mathrm{LT}$ & 1.138 & 0.081 & 14.090 & $* * *$ & 0.770 & & \\
\hline LT5 & $<-$ & $\mathrm{LT}$ & 0.945 & 0.076 & 12.392 & $* * *$ & 0.672 & & \\
\hline LT6 & $<-$ & $\mathrm{LT}$ & 1.063 & 0.078 & 13.643 & $* * *$ & 0.748 & & \\
\hline LT7 & $<-$ & $\mathrm{LT}$ & 1.094 & 0.077 & 14.125 & $* * *$ & 0.777 & & \\
\hline LT8 & $<-$ & LT & 0.880 & 0.072 & 12.189 & $* * *$ & 0.660 & & \\
\hline LT9 & $<-$ & LT & 1.113 & 0.082 & 13.618 & $* * *$ & 0.751 & & \\
\hline KA1 & $<-$ & KA & 1.000 & & & & 0.776 & \multirow{4}{*}{0.833} & \multirow{4}{*}{0.556} \\
\hline KA2 & $<-$ & KA & 0.998 & 0.069 & 14.389 & $* * *$ & 0.755 & & \\
\hline KA3 & $<-$ & KA & 0.832 & 0.067 & 12.475 & $* * *$ & 0.669 & & \\
\hline KA4 & $<-$ & KA & 1.043 & 0.069 & 15.137 & $* * *$ & 0.777 & & \\
\hline KI1 & $<-$ & KI & 1.000 & & & & 0.867 & \multirow{5}{*}{0.876} & \multirow{5}{*}{0.588} \\
\hline KI2 & $<-$ & KI & 0.975 & 0.054 & 18.205 & $* * *$ & 0.789 & & \\
\hline KI3 & $<-$ & $\mathrm{KI}$ & 0.902 & 0.059 & 15.266 & $* * *$ & 0.688 & & \\
\hline KI4 & $<-$ & KI & 0.961 & 0.054 & 17.794 & $* * *$ & 0.780 & & \\
\hline KI5 & $<-$ & KI & 0.825 & 0.053 & 15.537 & $* * *$ & 0.695 & & \\
\hline KU1 & $<-$ & $\mathrm{KU}$ & 1.000 & & & & 0.805 & \multirow{4}{*}{0.874} & \multirow{4}{*}{0.634} \\
\hline KU2 & $<-$ & KU & 0.833 & 0.050 & 16.751 & $* * *$ & 0.780 & & \\
\hline KU3 & $<-$ & $\mathrm{KU}$ & 0.804 & 0.054 & 14.921 & $* * *$ & 0.718 & & \\
\hline KU4 & $<-$ & KU & 1.060 & 0.055 & 19.286 & $* * *$ & 0.875 & & \\
\hline LP1 & $<-$ & LP & 1.000 & & & & 0.769 & \multirow{10}{*}{0.919} & \multirow{10}{*}{0.534} \\
\hline LP2 & $<-$ & LP & 0.992 & 0.066 & 15.116 & $* * *$ & 0.732 & & \\
\hline LP3 & $<-$ & $\mathrm{LP}$ & 0.969 & 0.069 & 14.065 & $* * *$ & 0.687 & & \\
\hline LP4 & $<-$ & $\mathrm{LP}$ & 0.947 & 0.069 & 13.704 & $* * *$ & 0.673 & & \\
\hline LP5 & $<-$ & $\mathrm{LP}$ & 0.984 & 0.064 & 15.484 & $* * *$ & 0.747 & & \\
\hline LP6 & $<-$ & LP & 0.998 & 0.060 & 16.695 & $* * *$ & 0.795 & & \\
\hline LP7 & $<-$ & $\mathrm{LP}$ & 0.931 & 0.069 & 13.595 & $* * *$ & 0.666 & & \\
\hline LP8 & $<-$ & $\mathrm{LP}$ & 0.858 & 0.061 & 14.059 & $* * *$ & 0.687 & & \\
\hline LP9 & $<-$ & $\mathrm{LP}$ & 0.968 & 0.063 & 15.434 & $* * *$ & 0.743 & & \\
\hline LP10 & $<-$ & $\mathrm{LP}$ & 1.073 & 0.064 & 16.843 & $* * *$ & 0.795 & & \\
\hline SC1 & $<-$ & SC & 1.000 & & & & 0.768 & \multirow{4}{*}{0.866} & \multirow{4}{*}{0.618} \\
\hline SC2 & $<-$ & SC & 1.005 & 0.061 & 16.572 & $* * *$ & 0.853 & & \\
\hline SC3 & $<-$ & $\mathrm{SC}$ & 0.839 & 0.056 & 14.968 & $* * *$ & 0.770 & & \\
\hline SC4 & $<-$ & SC & 0.850 & 0.058 & 14.779 & $* * *$ & 0.749 & & \\
\hline
\end{tabular}


Table 9 sums up the correlation coefficients among the six potential variables, in which the number of the diagonal lines is the square root of each variable AVE value. They range from 0.731 to 0.796 , and the absolute values of the correlation coefficients range from 0.202 to 0.635 . The square root of each variable AVE value is obviously larger than the correlation coefficient, which indicates that there is great discriminant validity between the six latent variables.

Table 9. Descriptive statistics correlation coefficient matrix.

\begin{tabular}{ccccccccc}
\hline & Mean & Standard Deviation & LT & KA & KI & KU & LP & SC \\
\hline LT & 4.414 & 1.432 & 0.742 & & & & & \\
KA & 3.952 & 1.495 & 0.458 & 0.746 & & & & \\
KI & 4.417 & 1.583 & 0.486 & 0.454 & 0.767 & & & \\
KU & 4.692 & 1.581 & 0.551 & 0.528 & 0.557 & 0.796 & & \\
LP & 4.425 & 1.582 & 0.533 & 0.584 & 0.610 & 0.635 & 0.731 & \\
SC & 4.028 & 1.534 & 0.202 & 0.340 & 0.399 & 0.371 & 0.368 & 0.786 \\
AVE & & & 0.551 & 0.556 & 0.588 & 0.634 & 0.534 & 0.618 \\
\hline
\end{tabular}

\subsection{Structural Equation Model}

In this paper, the structural equation model has been used to test the interrelationship between variables, and the structural equation model was analyzed by AMOS version 23.0. The results are shown in Table 10.

Table 10. Structural equation model fitting index.

\begin{tabular}{ccccc}
\hline Indicator & Statistic Value & Critical Value & Result & Model Fitting Judgment \\
\hline & $\chi^{2}$ & & 1602.150 & \\
df & & 1362 & NO \\
Absolute fitting & P & $\geq 0.05$ & 0.000 & YES \\
index & SRMR & $\leq 0.05$ & 0.036 & YES \\
& RMSEA & $\leq 0.08$ & 0.015 & Close to 0.9 \\
& GFI & $\geq 0.90$ & 0.891 & Close to 0.9 \\
Value-added fitting & NFI & $\geq 0.90$ & 0.892 & YES \\
index & IFI & $\geq 0.90$ & 0.982 & YES \\
& TLI & $\geq 0.90$ & 0.980 & YES \\
\hline & CFI & $\geq 0.90$ & 0.982 & YES \\
& PGFI & $\geq 0.50$ & 0.766 & YES \\
Simple fitting index & PNFI & $\geq 0.50$ & 0.817 & YES \\
& PCFI & $\geq 0.50$ & 0.899 & YES \\
& CN & $\geq 200$ & 712 & YES \\
\hline
\end{tabular}

The fitting index analysis of the structural equation model in this paper is shown in Table 11. The acceptable p-value of the evaluation model was 0.000 , which is less than 0.05 , and this is not up to the standard required. Therefore, the model is not acceptable. In addition, the GFI and NFI are close to 0.9 , which is acceptable, but the other indicators all fit very well, thus, they can be considered to be established and that the model is acceptable.

As shown in the Table 11, according to the results of empirical analysis, all 10 hypotheses are valid. 
Table 11. Structural equation model path analysis.

\begin{tabular}{|c|c|c|c|c|c|c|c|c|c|}
\hline & & & Estimate & S.E. & C.R. & $\mathbf{P}$ & $\begin{array}{l}\text { Standardized } \\
\text { Estimate }\end{array}$ & $\begin{array}{l}\text { Corresponding } \\
\text { Hypothesis }\end{array}$ & Result \\
\hline KA & $<-$ & LT & 0.496 & 0.066 & 7.574 & $* * *$ & 0.458 & Hypothesis 1a & True \\
\hline KI & $<-$ & LT & 0.431 & 0.074 & 5.842 & $* * *$ & 0.352 & Hypothesis $1 \mathrm{~b}$ & True \\
\hline KU & $<-$ & LT & 0.352 & 0.072 & 4.916 & *** & 0.285 & Hypothesis 1c & True \\
\hline KI & $<-$ & KA & 0.33 & 0.069 & 4.801 & **** & 0.293 & Hypothesis 2a & True \\
\hline KU & $<-$ & KI & 0.302 & 0.058 & 5.208 & $* * *$ & 0.299 & Hypothesis 2b & True \\
\hline KU & $<-$ & KA & 0.299 & 0.067 & 4.47 & $* * *$ & 0.263 & Hypothesis 2c & True \\
\hline LP & $<-$ & KA & 0.28 & 0.062 & 4.542 & $* * *$ & 0.253 & Hypothesis 3a & True \\
\hline LP & $<-$ & KI & 0.273 & 0.054 & 5.059 & $* * *$ & 0.279 & Hypothesis 3b & True \\
\hline LP & $<-$ & KU & 0.266 & 0.059 & 4.506 & $* * *$ & 0.274 & Hypothesis 3c & True \\
\hline LP & $<-$ & LT & 0.157 & 0.063 & 2.492 & 0.013 & 0.131 & Hypothesis 4a & True \\
\hline
\end{tabular}

\subsection{Multi-Group Structural Equation Model}

In order to study whether SC plays a regulatory role in the influence of LT on KA, KI, KU, and LP, this paper classifies SC into two groups according to the average scores. The average SC score was 4.028. There were 204 groups whose scores were lower than the average score and there were 190 groups whose scores were higher than the average score. The results of the multiple group regression are shown in Table 12.

Table 12. Multi-group structural equation model fitting index.

\begin{tabular}{ccccc}
\hline Indicator & Statistic Value & Critical Value & Restricted Model & $\begin{array}{c}\text { Unconstrained } \\
\text { Model }\end{array}$ \\
\hline & $\chi^{2}$ & & 1039.813 & 1062.819 \\
df & & 908.000 & 918.000 \\
Absolute fitting & P & $\geq 0.05$ & 0.001 & 0.001 \\
index & RMR & $\leq 0.05$ & 0.177 & 0.260 \\
& SRMR & $\leq 0.05$ & 0.054 & 0.020 \\
& RMSEA & $\leq 0.08$ & 0.019 & 0.861 \\
& GFI & $\geq 0.90$ & 0.864 & 0.840 \\
\hline Value-added fitting & AGFI & $\geq 0.90$ & 0.842 & 0.857 \\
index & NFI & $\geq 0.90$ & 0.860 & 0.845 \\
& RFI & $\geq 0.90$ & 0.847 & 0.978 \\
& IFI & $\geq 0.90$ & 0.980 & 0.976 \\
& TLI & $\geq 0.90$ & 0.978 & 0.977 \\
\hline CFI & $\geq 0.90$ & 0.980 & 0.749 \\
& PGFI & $\geq 0.50$ & 0.743 & 0.793 \\
& PNFI & $\geq 0.50$ & 0.787 & 0.905 \\
& PCFI & $\geq 0.50$ & 0.897 & 366.000 \\
\hline
\end{tabular}

In the multi-group structural equation model, we took the restricted model and the unconstrained model together in order examine whether there was a significant difference between the two groups. If there was a difference, the critical ratio t-test was used for each path. If the $t$-value was greater than 1.96 , this indicated the path was significantly different, i.e., in a different SC group, and that the regulation effect exists.

It can be seen from Table 13 that the p-value of the model difference test was 0.011 , which is less than 0.05 , indicating that the models have significant differences in their path effects as compared to in the t-test. The results of this are shown in Table 14. 
Table 13. The differences between restrictive and unconstrained models.

\begin{tabular}{cccccccc}
\hline Model & DF & CMIN & P & $\begin{array}{c}\text { NFI } \\
\text { Delta-1 }\end{array}$ & $\begin{array}{c}\text { IFI } \\
\text { Delta-2 }\end{array}$ & $\begin{array}{c}\text { RFI } \\
\text { rho-1 }\end{array}$ & $\begin{array}{c}\text { TLI } \\
\text { rho2 }\end{array}$ \\
\hline $\begin{array}{c}\text { Structural } \\
\text { weights }\end{array}$ & 10 & 23.006 & 0.011 & 0.003 & 0.004 & 0.002 & 0.002 \\
\hline
\end{tabular}

Table 14. Path analysis results for different SC groups.

\begin{tabular}{ccccccccc}
\hline & Path & & \multicolumn{2}{c}{ Low SC } & \multicolumn{2}{c}{ High SC } & \multicolumn{2}{c}{ Critical Ratios (95\%) } \\
\cline { 3 - 8 } & & & $\begin{array}{c}\text { Standardized } \\
\text { Estimate }\end{array}$ & $\mathbf{P}$ & $\begin{array}{c}\text { Standardized } \\
\text { Estimate }\end{array}$ & $\mathbf{P}$ & $\mathbf{T}$ & $\begin{array}{c}\text { Established } \\
\text { or Not }\end{array}$ \\
\hline KA & $<-$ & LT & 0.256 & 0.002 & 0.585 & $* * *$ & 3.187 & YES \\
KI & $<-$ & LT & 0.245 & 0.002 & 0.496 & $* * *$ & 2.581 & YES \\
KI & $<-$ & KA & 0.228 & 0.007 & 0.193 & 0.039 & -0.171 & NO \\
KU & $<-$ & LT & 0.225 & 0.004 & 0.391 & $* * *$ & 1.968 & YES \\
KU & $<-$ & KI & 0.260 & 0.001 & 0.279 & $* * *$ & -0.173 & NO \\
KU & $<-$ & KA & 0.241 & 0.004 & 0.208 & 0.014 & -0.436 & NO \\
LP & $<-$ & KA & 0.278 & $* * *$ & 0.179 & 0.028 & -0.856 & NO \\
LP & $<-$ & KI & 0.289 & $* * *$ & 0.224 & 0.006 & -0.710 & NO \\
LP & $<-$ & KU & 0.286 & $* * *$ & 0.219 & 0.018 & -0.346 & NO \\
LP & $<-$ & LT & 0.064 & 0.350 & 0.303 & 0.001 & 2.257 & YES \\
\hline
\end{tabular}

As can be seen from Table 14, the t-values of the path coefficient discriminatory tests in the high SC group and the low SC group were 3.187, 2.581, 1.968, and 2.257, respectively, which are all larger than 1.96. Here, the model reaches a significant level and indicates a significant difference between them. That is to say, under high SC conditions, the impact of LT on KA, KI, KU, and LT is significantly higher than that under low SC conditions. Here, the adjustment is established, and SC will promote the positive impact of LT to KA, KI, KU, and LT.

\section{Conclusions}

The concept of sustainable development in contemporary society fits the idea that lean implementation eliminates waste and maximizes value. To achieve sustainable development, lean is an effective method. However, the application of lean tools in specific domestic projects is not satisfactory. This paper has analyzed the application effects of lean tools from the viewpoint of knowledge management. It has discussed the influence of lean tools via the mediating role of knowledge management and the adjustment role of study conventions on lean sustainability. The theoretical hypotheses posed in this work have been supported by the results of the data analysis. It reveals the important role of knowledge management in lean sustainable development. Through theoretical and empirical analysis, the following significant conclusions are drawn:

(1) The adoption of lean tools has a positive impact on knowledge acquisition, knowledge integration, and knowledge application. For example, the use of concurrent engineering or BIM technology in the design phase can greatly promote the sharing and exchange of knowledge; the use of the value flow diagram in the lean implementation phase requires the conversion of tacit knowledge to explicit knowledge by lean implementation staff. The feedback in the plan execution process and the team members' thinking about the problem will enrich the tacit knowledge of the individual, thereby promoting the process of knowledge integration; and the use of these tools is actually the process of knowledge application.

(2) Most existing studies focus on the direct impact of the application of lean tools on lean sustainability and lack discussion on the role of activities of internal knowledge management between lean tools and lean sustainability. The application of lean tools has a direct positive impact on lean sustainability. However, without the intermediary role of knowledge management, lean tools can hardly exert their maximum effect, reflecting the importance of knowledge management in the application 
of lean tools. This paper has empirically studied the mediating role of knowledge management in the application of lean tools and lean sustainability, elucidating a better understanding of the internal application of lean tools and the learning behavior of lean knowledge.

(3) New knowledge will be generated in the process of lean sustainable development, and the new knowledge will promote the effect of lean implementation. Lean implementation focuses on performance evaluation, through which periodic problems are found and feasible solutions are proposed to managers to achieve continuous improvement. Whether it is the performance evaluation indicators, the root cause of the problem, or the solution to the problem, it is the new knowledge generated in the process of lean continuous improvement. Storing, recording, and applying new knowledge to the next phase plan will enable the next phase plan to be carried out at a higher level of knowledge, thus further promoting lean sustainability. This is like a continuous climbing process. Sustainable evaluation promotes the generation of knowledge, and the accumulated new knowledge reacts to the continuous improvement and improvement of lean.

(4) This article has implemented different patterns of regular behavior as study conventions, elucidating the effects of the adjustment of study conventions in the application of lean tools through empirical research. Distinct enterprises present a different degree of understanding and application of the same lean tool, and the corresponding performance becomes different. Enterprises with good study conventions could behave more orderly and efficiently in the process of the application and promotion of lean tools. Otherwise, their practice only remains a simple imitation. To begin to deal with this, enterprises can establish good study conventions in the organization, unify their ways of thinking, and form a cohesive force of common work.

From a practical viewpoint, this paper concludes by providing some relevant implications for enterprises applying lean tools. Knowledge is an indispensable factor in the application of lean tools. Enterprises achieve the goal of improving sustainability by continuously improving and innovating the application process of lean tools through knowledge acquisition, integration, and application. On the other hand, good study conventions can help enterprises to create and gather all kinds of lean knowledge. Therefore, enterprise managers should strengthen knowledge management activities in the process of lean implementation, strengthen knowledge acquisition, knowledge integration, and knowledge application, so as to promote the knowledge level of lean implementation continues to grow. This accumulation of experience and knowledge not only helps improve the quality of lean implementation, but also reduces production costs and promotes lean sustainability. At the same time, attention should also be paid to establishing good study conventions, allowing the promotion of a continuous growth of lean knowledge, consequently improving lean sustainability.

Author Contributions: Conceptualization, B.Z.; methodology, B.Z.; software, C.L.; validation, B.Z.; formal analysis, B.Z. and Z.N.; investigation, Z.N.; data curation, C.L.; Writing—original draft prepatation, B.Z. Writing—review and editing, C.L. and Z.N. All authors have read and agreed to the published version of the manuscript.

Funding: This research was funded by the National Natural Science Foundation of China [grant number 71071107].

Conflicts of Interest: Authors declare no conflicts of interest.

\section{References}

1. Honarpour, A.; Jusoh, A.; Long, C.S. Knowledge management and total quality management: A reciprocal relationship. Knowl. Manag. Tqm 2017, 34, 91-102.

2. Anand, G.; Ward, P.T.; Tatikonda, M.V. Role of explicit and tacit knowledge in six sigma projects: An empirical examination of differential project success. J. Oper. Manag. 2010, 28, 303-315. [CrossRef]

3. Acar, M.F.; Tarim, M.; Zaim, H.; Zaim, S.; Delen, D. Knowledge management and ERP: Complementary or contradictory? Int. J. Inf. Manag. 2017, 37, 703-712. [CrossRef]

4. Ataseven, C.; Nair, A. Assessment of supply chain integration and performance relationships: A meta-analytic investigation of the literature. Int. J. Prod. Econ. 2017, 185, 252-265. [CrossRef]

5. Tregear, A. Progressing knowledge in alternative and local food networks: Critical reflections and a research agenda. J. Rural Stud. 2011, 27, 419-430. [CrossRef] 
6. Blay-Palmer, A.; Santini, G.; Dubbeling, M.; Renting, H.; Taguchi, M.; Giordano, T. Validating the city region food system approach: Enacting inclusive, transformational city region food systems. Sustainability 2018, 10, 1680. [CrossRef]

7. Azadegan, A.; Patel, P.C.; Zangoueinezhad, A. The effect of environmental complexity and environmental dynamism on lean practices. J. Oper. Manag. 2013, 31, 193-212. [CrossRef]

8. Belekoukias, I.; Garza-Reyes, J.A.; Kumar, V. The impact of lean methods and tools on the operational performance of manufacturing organisations. Int. J. Prod. Res. 2014, 52, 5346-5366. [CrossRef]

9. Becker, M.C. A framework for applying organizational routines in empirical research: Linking antecedents, characteristics and performance outcomes of recurrent interaction patterns. Ind. Corp. Chang. 2005, 14, 817-846. [CrossRef]

10. Atkinson, R.; Dörfler, T.; Hasanov, M.; Rothfuss, E.; Smith, I. Making the case for self-organisation: Understanding how communities make sense of sustainability \& climate change through collective action. Int. J. Sustain. Soc. 2017, 9, 193-209.

11. Arumugam, V.; Antony, J.; Kumar, M. Linking learning and knowledge creation to project success in Six Sigma projects: An empirical investigation. Int. J. Prod. Econ. 2013, 141, 388-402. [CrossRef]

12. Bhasin, S. Performance of lean in large organisations. J. Manuf. Syst. 2013, 31, 349-357. [CrossRef]

13. Staats, B.R.; Brunner, D.J.; Upton, D.M. Lean principles, learning, and knowledge work: Evidence from a software services provider. J. Oper. Manag. 2011, 29, 376-390. [CrossRef]

14. Hasanov, M.; Zuidema, C. The transformative power of self-organization: Towards a conceptual framework for understanding local energy initiatives in the Netherlands. Energy Res. Soc. Sci. 2018, 37, 85-93. [CrossRef]

15. Loebbecke, C.; van Fenema, P.C.; Powell, P. Managing inter-organizational knowledge sharing. J. Strateg. Inf. Syst. 2016, 25, 4-14. [CrossRef]

16. Lin, H. Knowledge sharing and firm innovation capability: An empirical study. Int. J. Manpow. 2007, 28, 315-332. [CrossRef]

17. Ritala, P.; Husted, K.; Olander, H.; Michailova, S. External knowledge sharing and radical innovation: The downsides of uncontrolled openness. J. Knowl. Manag. 2018, 22, 1104-1123. [CrossRef]

18. Inkpen, A.C.; Tsang, E.W. Reflections on the 2015 decade award-Social Capital, networks, and knowledge transfer: An emergent stream of research. Acad. Manag. Rev. 2016, 41, 573-588. [CrossRef]

19. Albrecht, C.; Smithers, J. Reconnecting through local food initiatives? Purpose, practice and conceptions of 'value'. Agric. Hum. Values 2018, 35, 67-81. [CrossRef]

20. Breschi, S.; Lissoni, F. Localised knowledge spillovers vs innovative milieu: Knowledge 'tacitness' reconsidered. Pap. Reg. Sci. 2001, 80, 255-273. [CrossRef]

21. Browning, T.R.; Heath, R.D. Reconceptualizing the effects of lean on production costs with evidence from the F-22 Program. J. Oper. Manag. 2009, 27, 23-44. [CrossRef]

22. Camacho-Miñano, M.M.; Moyano-Fuentes, J.; Sacristán-Díaz, M. What can we learn from the evolution of research on lean management assessment? Int. J. Prod. Res. 2013, 51, 1098-1116. [CrossRef]

23. Carlile, P.R. Transferring, translating and transforming: An integrative framework for managing knowledge across boundaries. Organ. Sci. 2004, 15, 555-568. [CrossRef]

24. Carlile, P.R. A pragmatic view of knowledge and boundaries: Boundary objects in new product development. Organ. Sci. 2002, 13, 442-455. [CrossRef]

25. Carlile, P.R.; Rebentisch, E.S. Into the black box: The knowledge transformation cycle. Manag. Sci. 2003, 49, 1180-1195. [CrossRef]

26. Phong, L.B.; Hui, L.; Son, T.T. How leadership and trust in leaders foster employees' behavior toward knowledge sharing. Soc. Behav. Pers.: Int. J. 2018, 46, 705-720. [CrossRef]

27. Lynch, R.; Jin, Z. Knowledge and innovation in emerging market multinationals: The expansion paradox. J. Bus. Res. 2016, 69, 1593-1597. [CrossRef]

28. Delery, J.E.; Roumpi, D. Strategic human resource management, human capital and competitive advantage: Is the field going in circles? Hum. Res. Manag. J. 2017, 27, 1-21. [CrossRef]

29. Prajogo, D.I.; Oke, A. Human capital, service innovation advantage, and business performance: The moderating roles of dynamic and competitive environments. Int. J. Oper. Prod. Manag. 2016, 36, 974-994. [CrossRef]

30. Ritala, P.; Olander, H.; Michailova, S.; Husted, K. Knowledge sharing, knowledge leaking and relative innovation performance: An empirical study. Technovation 2015, 35, 22-31. [CrossRef] 
31. Boadu, F.; Xie, Y.; Du, Y.F.; Dwomo-Fokuo, E. MNEs subsidiary training and development and firm innovative performance: The moderating effects of tacit and explicit knowledge received from headquarters. Sustainability 2018, 10, 4208. [CrossRef]

32. Chavez, R.; Gimenez, C.; Fynes, B. Internal lean practices and operational performance: The contingency perspective of industry clockspeed. Int. J. Oper. Prod. Manag. 2013, 33, 562-588. [CrossRef]

33. Chavez, R.; Yu, W.; Jacobs, M. Internal lean practices and performance: The role of technological turbulence. Int. J. Prod. Econ. 2015, 160, 157-171. [CrossRef]

34. Cil, I.; Turkan, Y.S. An ANP-based assessment model for lean enterprise transformation. Int. J. Adv. Manuf. Technol. 2013, 64, 1113-1130. [CrossRef]

35. Demeter, K.; Matyusz, Z. The impact of lean practices on inventory turnover. Int. J. Prod. Econ. 2011, 133, 154-163. [CrossRef]

36. Frank, A.G.; Ribeiro, J.L.D. Influence factors and process stages of knowledge transfer between NPD teams: A model for guiding practical improvements. Int. J. Qual. Reliab. Manag. 2014, 31, 222-237. [CrossRef]

37. Fullerton, R.R.; Wempe, W.F. Lean manufacturing, non-financial performance measures and financial performance. Int. J. Oper. Prod. Manag. 2009, 29, 214-240. [CrossRef]

38. Xie, Y.; Du, Y.F.; Boadu, F.; Shi, X.Y. Executives assessments of evolutionary and leapfrog modes: An ambidexterity explanation logic. Sustainability 2018, 10, 2893. [CrossRef]

39. Chowhan, J.; Pries, F.; Mann, S. Persistent innovation and the role of human resource management practices, work organization, and strategy. J. Manag. Organ. 2017, 23, 456-471. [CrossRef]

40. Garud, R.; Nayyar, P.R. Transformative capacity: Continual structuring by intertemporal technology transfer. Strateg. Manag. J. 1994, 15, 365-385. [CrossRef]

41. Garrick, J.; Chan, A.; Carayannis, E.; Bedford, D. Knowledge management and professional experience: The uneasy dynamics between tacit knowledge and performativity in organizations. J. Knowl. Manag. 2017, 21, 872-884. [CrossRef]

42. Maravilhas, S.; Martins, J. Strategic knowledge management in a digital environment: Tacit and explicit knowledge in Fab Labs. J. Bus. Res. 2019, 94, 353-359. [CrossRef]

43. Kaabi, A.A.A.; Elanain, H.A.; Ajmal, M.M. HRM practices and innovation performance with the mediating effect of knowledge sharing: Empirical evidence from Emirati ICT companies. Int. J. Innov. Learn. 2018, 24, 41-61. [CrossRef]

44. Ahmad, A.; Bosua, R.; Scheepers, R. Protecting organizational competitive advantage: A knowledge leakage perspective. Comput. Secur. 2014, 42, 27-39. [CrossRef]

45. Furlan, A.; Vinelli, A.; Dal Pont, G. Complementarity and lean manufacturing bundles: An empirical analysis. Int. J. Oper. Prod. Manag. 2011, 31, 835-850. [CrossRef]

46. Hales, M.; Tidd, J. The practice of routines and representations in design and development. Ind. Corp. Chang. 2009, 18, 551-574. [CrossRef]

47. Jansen, J.J.P.; Van den Bosch, F.A.J.; Volberda, H.W. Managing Potential and Realized Absorptive Capacity: How do Organizational Antecedents matter? Acad. Manag. J. 2005, 48, 999-1015. [CrossRef]

48. Yusr, M.M.; Mokhtar, S.S.M.; Othman, A.R.; Sulaiman, Y. Does interaction between TQM practices and knowledge management processes enhance the innovation performance? Int. J. Qual. Reliab. Manag. 2017, 34, 955-974. [CrossRef]

49. Arnett, D.B.; Wittmann, C.M. Improving marketing success: The role of tacit knowledge exchange between sales and marketing. J. Bus. Res. 2014, 67, 324-331. [CrossRef]

50. Teng, L.; Huang, D.; Pan, Y. The performance of MNE subsidiaries in China: Does it matter to be close to the political or business hub? J. Int. Manag. 2017, 23, 292-305. [CrossRef]

51. Barkema, H.G.; Chen, X.P.; George, G.; Luo, Y.; Tsui, A.S. West meets east: New concepts and theories. Acad. Manag. J. 2015, 58, 460-479. [CrossRef]

52. Maryam, A.; Dorothy, E.L. Review knowledge management and knowledge management systems: Conceptual foundations and research issues. Mis Q. 2001, 25, 107-136.

53. Nair, A. Meta-analysis of the relationship between quality management practices and firm performance-Implications for quality management theory development. J. Oper. Manag. 2006, 24, 948-975. [CrossRef]

54. Reich, B.H.; Gemino, A.; Sauer, C. How knowledge management impacts performance in project: An empirical study. Int. J. Proj. Manag. 2014, 32, 590-602. [CrossRef] 
55. Tyagi, S.; Cai, X.; Yang, K. Terrence chambers. Lean tools and methods to support efficient knowledge creation. Int. J. Inf. Manag. 2015, 35, 204-214. [CrossRef]

56. Zaefarian, G.; Forkmann, S.; Mitrega, M.; Henneberg, S.C. A capability perspective on relationship ending and its impact on product innovation success and firm performance. Long Range Plan. 2017, 50, 184-199. [CrossRef]

57. Shahram, T.; Cristian, M. The impact of lean operations on the Chinese manufacturing performance. J. Manuf. Technol. Manag. 2011, 22, 223-240.

58. Shah, R.; Ward, P.T. Lean manufacturing: Context, practice bundles and performance. J. Oper. Manag. 2003, 21, 129-149. [CrossRef]

59. Subramaniam, M.; Youndt, M.A. The influence of intellectual capital on the types of innovative capabilities. Acad. Manag. J. 2005, 48, 450-463. [CrossRef]

60. Zheng, W.; Yang, B.; McLean, G.N. Linking organizational culture, structure, strategy, and organizational effectiveness: Mediating role of knowledge management. J. Bus. Res. 2010, 63, 763-771. [CrossRef]

61. Ramadani, V.; Abazi-Alili, H.; Dana, L.P.; Rexhepi, G.; Ibraimi, S. The impact of knowledge spillovers and innovation on firm-performance: Findings from the balkans countries. Int. Entrep. Manag. J. 2017, 13, 299-325. [CrossRef]

62. Liu, S.; Leat, M.; Moizer, J.; Megicks, P.; Kasturiratne, D. A decision-focused knowledge management framework to support collaborative decision making for lean supply chain management. Int. J. Prod. Res. 2013, 51, 2123-2137. [CrossRef]

63. Tyagi, S.; Cai, X.; Yangk, K. Lean Tools and Methods to Support Efficient Kowledge Creation. Int. J. Inf. Manag. 2015, 35, 204-214. [CrossRef]

64. Wiengarten, F.; Gimenez, C.; Fynes, B. Exploring the importance of cultural collectivism on the efficacy of lean practices: taking an organisational and national perspective. Int. J. Oper. Prod. Manag. 2015, 35, 370-391. [CrossRef]

65. Zahra, S.A.; George, G. Absorptive capacity: A review, reconceptualization and extension. Acad. Manag. Rev. 2002, 27, 185-203. [CrossRef]

66. Zwain, A.A.A.; Teong, L.K.; Othman, S.N. TQM practices and organisational knowledge creation: An empirical study of Iraqi higher education institutions. Asian J. Bus. Account. 2014, 7, 1-28.

(C) 2020 by the authors. Licensee MDPI, Basel, Switzerland. This article is an open access article distributed under the terms and conditions of the Creative Commons Attribution (CC BY) license (http://creativecommons.org/licenses/by/4.0/). 